Louisiana State University

LSU Digital Commons

Faculty Publications

Department of Biological Sciences

$5-1-2006$

\title{
Pine savanna overstorey influences on ground-cover biodiversity
}

William J. Platt

Louisiana State University

Susan M. Carr

Louisiana State University

Matthew Reilly

Boys and Girls Clubs of Southeast Louisiana

Jean Fahr

Boys and Girls Clubs of Southeast Louisiana

Follow this and additional works at: https://digitalcommons.Isu.edu/biosci_pubs

\section{Recommended Citation}

Platt, W., Carr, S., Reilly, M., \& Fahr, J. (2006). Pine savanna overstorey influences on ground-cover biodiversity. Applied Vegetation Science, 9 (1), 37-50. https://doi.org/10.1658/

1402-2001(2006)9[37:PSOIOG]2.0.CO;2

This Conference Proceeding is brought to you for free and open access by the Department of Biological Sciences at LSU Digital Commons. It has been accepted for inclusion in Faculty Publications by an authorized administrator of LSU Digital Commons. For more information, please contact ir@lsu.edu. 


\title{
Pine savanna overstorey influences on ground-cover biodiversity
}

\author{
Platt, William J. ${ }^{1^{*}}$; Carr, Susan M..$^{1,3}$; Reilly, Matthew ${ }^{2,4}$ \& Fahr, Jean ${ }^{2,5}$ \\ ${ }^{1}$ Department of Biological Sciences, 202 LSB, Louisiana State University, Baton Rouge, LA 70803, USA; \\ ${ }^{2}$ Girl Scout Council of Southeast Louisiana, 841 South Clearview Parkway, New Orleans, LA 70121, USA; \\ ${ }^{3}$ Department of Wildlife Conservation and Ecology, 110 Newins-Zeigler Hall, University of Florida, Gainesville, FL \\ 32611-0430, USA; ${ }^{4}$ Current address: School of Forest Resources, University of Georgia, Athens, Georgia 30602, \\ USA; ${ }^{5}$ Executive Director, Parkway Partners Program, 1137 Baronne Street, New Orleans, LA 70113, USA; \\ *Corresponding author;E-mail btplat@lsu.edu
}

\begin{abstract}
Question: Does the overstorey of pine savannas influence plant species biodiversity in the ground cover?

Location: Camp Whispering Pines (3041' N; 90²9' W), eastern Louisiana (USA).

Methods: We used ecologically sensitive restoration logging to remove patches of Pinus palustris (longleaf pine) in a second-growth loess plain Pinus palustris savanna managed using frequent lightning season fires. Five years later, we measured numbers of vascular plant species and transmitted light in replicated $100-\mathrm{m}^{2}$ plots. Treatments involved three different overstorey conditions: no overstorey for 5 years, no overstorey for several decades, and overstorey pines present for decades.

Results: Both recent and long-term openings contained, on average, about 100 vascular plant species per $100 \mathrm{~m}^{2}, 20 \%$ more than in similar-sized areas beneath overstorey trees. Responses varied with life form; more herbaceous species occurred in recent and older overstorey openings than beneath overstorey trees. Total numbers of all species and of less abundant forb species were positively and linearly related to light transmitted to ground level. Those species responding to openings in the overstorey and positively associated with increased transmitted light levels were monocarpic and shortlived perennial forb and grass species with a seed bank in the soil. In addition, community structure, as reflected in species composition and abundances, appeared to vary with canopy condition.

Conclusions: Restoration involving ecologically sensitive removal of patches of overstorey pines in frequently burned pine savannas should benefit the ground cover and increase plant species biodiversity as a result of increased abundance of seed bank species.
\end{abstract}

Keywords: Fire; Longleaf pine; Louisiana; Pinus palustris; Restoration.

Abbreviations: $\mathrm{CWP}=$ Camp Whispering Pines; $\mathrm{MRPP}=$ Multi-response permutation procedures.

\section{Introduction}

Pine savanna/woodland ecosystems, historically spread across the southeastern United States, have almost disappeared over the past century (Means \& Grow 1985; Means 1996; Platt 1999). Most remaining fragments have been greatly altered and no longer resemble old-growth stands (e.g. Noel et al. 1998). As a result, indigenous flora and fauna are considered threatened (Folkerts et al. 1993; Guyer \& Bailey 1993; Peet \& Allard 1993; Means 1996; James et al. 1997; Platt 1999). Two non-exclusive approaches to restoration have been proposed, based on study of ecological processes and structure of old-growth stands (e.g. Platt et al. 1988; Noel et al. 1998).

First, prescribed fire has been used in management of pine savanna/woodland systems for many decades. Only over the past couple decades, however, have prescribed fires mimicking the frequent, lightning-initiated fires that were historically an integral part of the environment been used to guide ecological restoration (Doren et al. 1993; Whelan 1995; Platt 1999; Beckage et al. 2005). Field experiments have demonstrated that such fires enhance herbaceous-dominated ground cover, prevent spread of shrubs, and suppress hardwood trees, producing vegetation cover patterns that resemble those postulated to characterize pine savannas historically (Platt et al. 1988, 1991; Brewer \& Platt 1994a, b; Glitzenstein et al. 1995; Olson \& Platt 1995; DeCoster et al. 1999; Beckage \& Stout 2000; Schmitz et al. 2002; Drewa et al. 2002a, b; Slocum et al. 2003).

Second, overstorey trees need to be managed ecologically. Study of frequently burned old-growth stands has revealed a patch structure involving spatially discontinuous age and size classes, as well as some space containing no large living pines (Platt et al. 1998; Doren et al. 1993; Gilliam et al. 1993; Grace \& Platt 1995a, b; Noel et al. 1998). Such openings were generated naturally by lightning, windthrows, and hurricanes (Platt \& Rathbun 1993; Platt et al. 2000, 2002; 
Gilliam \& Platt 1999, 2006). The patchy spatial structure has been postulated to influence the ground cover and the fauna, as well as fire characteristics (Platt et al. 1991; Glitzenstein et al. 1995; James et al. 1997; Brewer 1998b; Brockway et al. 1998; DeCoster et al. 1999; Mulligan et al. 2002). Thus, opening of densely-stocked second-growth stands has been proposed as a management option to generate more uneven sized stands of trees, as well as a more open savanna-woodland aspect that would facilitate conservation of biodiversity (Noel et al. 1998).

How might opening the overstorey of pines affect the ground cover? Openings that increase light levels have long been recognized as important for 'early species' (Platt \& Connell 2003) in many plant communities. Often such species are present after disturbance, but do not persist over long periods of time as above-ground members of communities once shaded. For example, gap-dependent herbs and trees occur in temperate and tropical closed canopy forests (e.g. Collins et al. 1985; Horvitz \& Schemske 1985; Poulson \& Platt 1989, 1996, Guzman-Grajales \& Walker 1991; Ferguson et al. 1995; Vandermeer et al. 1996; Hjerpe et al. 2001), fugitive forbs colonize locally disturbed places in grasslands and prairies (e.g., Platt 1975, 1976; Williams et al. 1986; Martinsen et al. 1990; McIntyre et al. 1995), and graminoids and forbs invade mangrove forests opened by hurricanes (Baldwin et al. 2001).

The overstorey in pine savannas/woodlands is periodically opened by disturbance. Such openings commonly persist in old-growth stands for decades (Platt et al. 1998). These openings are widely recognized as important for regeneration of trees, both pines and hardwoods (Rebertus et al. 1989a, b, 1993; Grace \& Platt 1995a, b; Palik et al. 1997; Brockway \& Outcalt 1998; McGuire et al. 2001). Overstorey openings also result in responses by the ground cover, especially increased growth of dominant grasses and shrubs (Platt et al. 1991; Brockway et al. 1998; Harrington \& Edwards 1999; Kush et al. 1999; McGuire et al. 2001; Jones et al. 2003). In addition, recruitment may potentially increase numbers of ground-cover species in overstorey openings (Brewer 1998b; Brockway et al. 1998; Mulligan et al. 2002).

We explored effects of removal of overstorey pines on numbers of plant species in the ground cover. We hypothesized that ecologically sensitive restoration logging, which involved removal of patches of overstorey trees and produced openings resembling those naturally generated by hurricanes with only minor soil disturbance, should result in increased numbers of species in the ground cover. We further predicted that increases in light levels associated with removal of the overstorey should be associated with increases in the abundance of less common species not often found beneath overstorey trees. We used a species-rich second-growth Louisiana loess plain pine savanna with a dense overstorey of Pinus palustris (longleaf pine) and managed using biennial prescribed fires during the summer lightning season. Use of this site enhanced our ability to test for differences in species composition and also remove potential confounding effects of infrequent fires. Five years after logging, we measured transmitted light and compared the numbers of vascular plant species in areas that were opened by canopy removal, areas that had been open for at least several decades, and areas that had overstorey pines for many decades.

\section{Methods}

\section{Study site and land-use history}

Camp Whispering Pines (3041' N; 90²9' W) is in Tangipahoa Parish in the eastern Louisiana loess plains. This site, $<80 \mathrm{~km}$ east of the Mississippi River, is near the western edge of the eastern Gulf coastal plain. The dissected terrain, 25 - $50 \mathrm{~m}$ above mean sea level, contains Pleistocene-aged, Tangi-Ruston-Smithdale fine sands that are mixed with and capped by deposits of wind-blown loess; in places, a fragipan is located below the surface (McDaniel 1990). Camp Whispering Pines (hereafter CWP) contains even-sized second-growth stands of Pinus palustris (Noel et al. 1998) and a diverse ground cover dominated by large warm-season grasses:

\footnotetext{
Andropogon gerardi Andropogon virginicus var. decipiens Aristida purpurescens Panicum anceps Panicum virgatum Schizachyrium scoparium

Schizachyrium tenerum Sorghastrum nutans

Sporobolus clandestinus
}

as well as smaller $\mathrm{C} 3$ grasses:
Dichanthelium acuminatum
D. ovale
D. angustifolium
D. strigosum
D. tenue

These plant communities resemble, to some extent, others in the western part of the eastern Gulf coastal plain (e.g. Peet \& Allard 1993).

Anthropogenic land use of the CWP landscape began after the American Civil War, ca. 1870. Initial settlement of the region fragmented the landscape and altered plant communities to some unknown extent (Table 1). Anthropogenic effects in the early 20th century included logging of large trees, turpentining of residual trees, and conversion of cut-over areas to agricultural use. Regeneration by 'cull' trees and release of small trees when large trees were logged produced dense stands of even-sized pines about 60 - 90 years old in the 1990s (Noel et al. 1998). Remaining old- 
Table 1. Known land use history of pine savannas at Camp Whispering Pines, Tangipahoa Parish, Louisiana. For each listing in the time sequence, the condition of the pine savanna landscape, and important events are listed for pine savannas at CWP.

\begin{tabular}{|c|c|c|}
\hline Time period & Landscape condition & Events \\
\hline $\begin{array}{l}\text { Up to late } \\
1800 \mathrm{~s}\end{array}$ & $\begin{array}{l}\text { Presettlement Condition: upland old-growth } \\
\text { longleaf pine and diverse ground cover }\end{array}$ & $\begin{array}{l}\text { Natural disturbances (lightning initiated fires, hurricanes) in eastern Louisiana Loess } \\
\text { plains landscape }\end{array}$ \\
\hline $\begin{array}{l}\text { Late } 1800 \text { s to } \\
\text { early } 1900 \mathrm{~s}\end{array}$ & $\begin{array}{l}\text { Initial habitat alterations begin to alter } \\
\text { the landscape }\end{array}$ & $\begin{array}{l}\text { Roads cause landscape fragmentation,open-range grazing and periodic dormant season } \\
\text { fires }\end{array}$ \\
\hline $1920 s-1930 s$ & Major habitat alterations & $\begin{array}{l}\text { Logging of large pines; turpentining of residual trees, part of landscape converted } \\
\text { to human agriculture }\end{array}$ \\
\hline $1930 s-1940 s$ & Regeneration of Pinus palustris & $\begin{array}{l}\text { Regeneration of young pines from residual trees; open-range grazing and periodic } \\
\text { dormant season fires }\end{array}$ \\
\hline $1960 s-1970 s$ & $\begin{array}{l}\text { Second-growth pine savanna with dense } \\
\text { stocking of trees }\end{array}$ & $\begin{array}{l}\text { Girl scouts purchase land, develop rustic camp, further fragmenting the landscape; } \\
\text { logging of last residual large pines; last record of red-cockaded woodpecker }\end{array}$ \\
\hline $1980 \mathrm{~s}$ & $\begin{array}{l}\text { Second-growth pine savanna with dense } \\
\text { stocking of trees and degraded ground cover }\end{array}$ & $\begin{array}{l}\text { Fire suppression by Girl scouts; Invasion by native and exotic trees and shrubs. } \\
\text { Gopher tortoises disappear from CWP }\end{array}$ \\
\hline 1992-1993 & $\begin{array}{l}\text { Degraded pine savanna with dense second- } \\
\text { growth trees and shrub-dominated ground cover }\end{array}$ & $\begin{array}{l}\text { First early lightning season fires (April) in different burn compartments established } \\
\text { at CWP }\end{array}$ \\
\hline 1994 & $\begin{array}{l}\text { Degraded second-growth pine savanna } \\
\text { with dense trees and shrub-dominated } \\
\text { ground cover }\end{array}$ & $\begin{array}{l}\text { Development of CWP Management Plan; prescribed lightning season fires in April \& } \\
\text { May; each year some CWP pine savannas are burned on a biennial schedule; } \\
\text { Pinus palustris mast year }\end{array}$ \\
\hline 1996 & $\begin{array}{l}\text { Second-growth pine savanna } \\
\text { with dense stocking of trees and ground cover } \\
\text { with reduced shrub dominance }\end{array}$ & $\begin{array}{l}\text { Restoration Forestry Program Initiated; off-site species and patches of Pinus palustris } \\
\text { removed to open space for regeneration; herbicides used on exotic shrubs in selected } \\
\text { areas }\end{array}$ \\
\hline 2001 & $\begin{array}{l}\text { Second-growth pine savanna in process of } \\
\text { restoration of overstorey and understorey }\end{array}$ & $\begin{array}{l}\text { Assessment of effects of restoration logging on ground cover in fall after early } \\
\text { lightning season fires: this study }\end{array}$ \\
\hline 2003-2004 & $\begin{array}{l}\text { Second-growth pine savanna in process of } \\
\text { restoration of overstorey and understorey }\end{array}$ & $\begin{array}{l}\text { Grass stages from } 1994 \text { mast year enter height growth in open areas from which pines } \\
\text { were removed; open vista achieved through six biennial early lightning } \\
\text { season fires in pine savannas; Pinus palustris mast year }\end{array}$ \\
\hline
\end{tabular}

growth, turpentine-scarred trees were logged, and fire suppression was instituted in the late 1960s, when CWP was acquired by the Girls Scouts of Southeastern Louisiana (Table 1). Over the next two decades, camping units were developed in localized areas within the site, and a headquarters was located in a central section that was the most disturbed. Tracts of hundreds of hectares of native habitat remained on the site, but became degraded as a result of fire suppression and invasion by exotic shrubs and vines (primarily Ligustrum sinense, Triadica sebifera, Lygodium japonicum).

CWP was identified as an ecologically significant site in the early 1990s (Table 1). An adaptive forest management plan instituted an aggressive prescribed fire program involving biennial spring (April-May) fires in 1994 and selective thinning of pine stands in 1996. Logging was based on comparisons of tree densities in old- and second growth Pinus palustris stands (Noel et al. 1998) and involved group selection (Matthews 1991). The goals were to open space for regeneration of pines and ground cover, benefit native wildlife utilizing such openings, and provide income to support restoration and management actions at CWP.

\section{Field design and sampling}

An experimental opening was generated in each of eight 1-ha plots containing mapped pines (Noel et al. 1998). Patch size was based on openings in which regeneration occurred on the Wade Tract and data from other studies (Platt et al. 1998; Platt \& Rathbun 1993; Grace \& Platt 1995a,b; Palik et al. 1997, 2003; Brockway \& Outcalt 1998; McGuire et al. 2001; Battaglia et al. 2002). One experimental opening of $1 / 10$ ha (ca. $10 \%$ of the pines) was generated inside each plot in 1996. Patches were randomly selected, subject to restrictions that a continuous overstorey of Pinus palustris was present, and that resulting openings not overlap edges of plots. The consulting forester worked with a local, small logging crew to remove entire trees carefully, with minimal soil disruption and damage of surrounding trees and ground cover. Trees were cut at the base; boles and crowns were dragged from areas cleared using skidders. Residual limbs and needles were distributed throughout the area being logged (but not at the bases of trees) to avoid large accumulations of fuels. All logging occurred in areas burned the previous year, so that a mat of ground cover and needles cushioned logging equip- 
ment, and tree removal was conducted during the fall dry period, when soils were most able to support equipment and when risk of lightning fires was minimal (see Olson \& Platt 1995).

Subplots were established in 2001. Three locations were selected randomly in each plot. First, a point was selected within the logged patch, subject to the restriction that it was $\geq 10 \mathrm{~m}$ from the nearest living pine. A second point was selected in a patch that had been without an overstorey for $\geq 3$ decades within each plot (based on aerial photography), again subject to the restriction that the point was $\geq 10 \mathrm{~m}$ from the nearest pine. A third point was selected that had continuous cover of overstorey pines within $10 \mathrm{~m}$ in all directions. These three points were used as the centre of non-overlapping $10 \mathrm{~m} \times 10 \mathrm{~m}\left(100 \mathrm{~m}^{2}\right)$ subplots established in 2001 . Vascular plant species present in each of these 24 subplots were recorded in fall 2001. The following spring (2002), each plot was again censused to check for spring ephemeral species and missed species. Total numbers of different species recorded in the two samples were used in analyses. Voucher specimens have been deposited in the Louisiana State University herbarium. Nomenclature followed Weakley (1999); identifications were checked with specimens in the LSU herbarium.

The total number of species per subplot was decomposed into categories. First, we classified species by plant life form. Each of the 251 species recorded was assigned one of three life forms: Forbs, Graminoids, and Shrubs. 'Forbs' were mostly dicots, but included herbaceous members of several families of monocots (Hypoxidaceae, Iridaceae, Orchidaceae and Liliaceae). 'Graminoids' were all herbaceous monocots in the families Cyperaceae and Poaceae. 'Shrubs' included smallerstature shrubs and hardwood trees $<1.5 \mathrm{~m}$ tall that produce persistent woody tissue. More than twice as many species were classified as Forbs than as either Graminoids or Shrubs (Table 2). Second, species within each life form were classified by frequency of occurrence, measured as the proportion of the 24 subplots in which that species occurred. Each species in a life form was assigned one of three frequencies: Common, Intermediate, or Infrequent. Frequency was assigned on the basis of equal intervals of proportions of occurrence within life forms; each frequency contained roughly a third of the total number of species within a life form. Numbers of species and proportions of subplots containing different frequencies of forbs, graminoids and shrubs are presented in Table 2.

We estimated the amount of light transmitted to the understorey in each subplot. We used photographs taken with a Nikon $8 \mathrm{~mm}$ hemispherical fisheye lens on a Nikon 4500 Coolpix digital camera mounted on a tripod at canopy height $(0.5 \mathrm{~m})$ above ground level. Photographs were taken within two hours on a single, uniformly overcast day in March, 2003. Several photographs were taken at the centre of each plot; the camera was leveled to horizontal position and the lens to a uniform 0 degree orientation. Photographs with the best contrast were retained for analysis. Digital images of hemispherical photographs were analyzed using the computer software gap light analyzer, Version 2.0 (GLA; Frazer et al. 1999). Geographic location and temporal information specific to the research site were entered for calculations. Images were registered and converted into working bitmap images containing black and white pixels (sky and non-sky), by setting a uniform 'threshold' level of contrast. Light transmission was calculated from working images, including estimations of direct, diffuse, and total solar radiation (in mol. $\mathrm{m}^{-2} \cdot \mathrm{d}^{-1}$ ). For analyses, we used percent transmitted total light (ratio of total transmitted direct and diffuse radiation to the total radiation above the canopy that is contributed by each sky region), assuming no effect of topography. As we were interested in relative variation among canopy conditions, and not quantification of absolute radiation, we used single measurements per plot. It has been shown that single light measurements are sufficient for relative comparisons of understory light conditions among sites (Engelbrecht \& Herz 2001).

Table 2. The 251 ground-cover vascular plant species in the $24100-\mathrm{m}^{2}$ subplots at Camp Whispering Pines were divided into life forms (forbs, graminoids, shrubs). Three abundance groups (Common, Intermediate, Infrequent) for each life form were based on the proportion of subplots in which a species in that life form occurred. The three abundance groups, designated on the basis of equal widths of abundance classes separately for each life form group, resulted in somewhat similar numbers of species within the abundance groups for each life form.

\begin{tabular}{|c|c|c|c|c|c|c|}
\hline \multirow[t]{2}{*}{ Abundance } & \multicolumn{2}{|c|}{ Forbs } & \multicolumn{2}{|c|}{ Graminoids } & \multicolumn{2}{|c|}{ Shrubs } \\
\hline & $\begin{array}{c}\text { Proportion } \\
\text { of plots }\end{array}$ & $\begin{array}{l}\text { Number } \\
\text { of species }\end{array}$ & $\begin{array}{l}\text { Proportion } \\
\text { of plots }\end{array}$ & $\begin{array}{l}\text { Number } \\
\text { of species }\end{array}$ & $\begin{array}{l}\text { Proportion } \\
\text { of plots }\end{array}$ & $\begin{array}{l}\text { Number } \\
\text { of species }\end{array}$ \\
\hline Total numbers of species & & 145 & & 47 & & 59 \\
\hline Common & $>0.45$ & 55 & $>0.74$ & 18 & $>0.54$ & 21 \\
\hline Intermediate & $>0.20$ and $<0.45$ & 43 & $>0.16$ and $<0.74$ & 15 & $>0.16$ and $<0.54$ & 19 \\
\hline Infrequent & $<0.20$ & 47 & $<0.16$ & 14 & $<0.16$ & 19 \\
\hline
\end{tabular}




\section{Data analysis}

The study is based on a randomized block design without replication. Each fixed-effects model includes Blocks $(n=8)$ and Overstorey Condition $(n=3)$, for 24 samples. As our questions involve main effects of canopy condition, tests of these effects are not dependent on the assumption of no treatment by block interaction (Sokal \& Rohlf 1995). We assume that block effects are random.

We used a combination of MANOVA and univariate ANOVA and ANCOVA models to assess effects of overstorey condition on numbers of plant species. Our specific hypotheses concerned (1) the effects of overstorey absent (A) or present $(\mathrm{P})$, and (2) the effects of recent (A5) vs. older (A30) openings. For each multi- or univariate model, these hypotheses were tested via two a priori orthogonal contrasts (Contrast 1: Ho: (A5+A30)/ $2=\mathrm{P}$; Contrast 2: Ho: A5 =A30). We tested each pair of contrasts at $\alpha=0.005$ to control the experiment-wise Type I error rate (approximate experiment-wise $\alpha=$ 0.08 ). We used Roy's gcr criterion in all multivariate $F$ tests of main effects and contrasts (Tabachnick \& Fidell 1996). All tests had either two levels only $(d f=1)$ or first eigenvalues $>90 \%$ of total explained variation. Evaluations of normality and variance/covariance homogeneity for MANOVA and ANOVA models were satisfactory. All response variables in this study are counts (discrete integers). For all univariate models, we compared model assumptions and distributions of residuals between ANOVA (or ANCOVA) and Poisson regression models. Poisson regressions provided better model fit for response variables characterized by low count numbers and many zeros. For this reason, we report results of ANOVA/ANCOVA tests for response categories with higher mean counts, and Poisson regressions for those with low count means. All statistical models were performed using GLM and GENMOD procedures (SAS Version 8.01, 1999).

We tested effects of canopy condition on three categories of responses. First, a RCB ANOVA was run using total number of species (per $100 \mathrm{~m}^{2}$ ) as a single dependent variable, and canopy condition and block as independent variables. Second, a similar MANOVA was performed on three dependent variables representing the partitioning of species number by life form (Forbs, Graminoids and Shrubs). Post-hoc univariate models were used to assess canopy effects on numbers of species within the three life forms separately. Partial correlation structure (in the MANOVA) indicated a pair of correlated life form dependent variables. In this case, we analysed canopy effects on one correlated variable by including its correlate as a covariate in an ANCOVA (similar to Roy-Bargmann stepdown analysis, sensu Tabachnick \& Fidell 1996). Dependent variables free of significant partial correlations were responses in separate post-hoc ANOVAs. Third, the same process was repeated using species counts partitioned by frequency within the Forb life form class (Common, Intermediate, and Infrequent Forbs). Each dependent variable (frequency count) was included in a Poisson regression model of Block and Canopy Condition effects. To account for partial correlations between frequency classes, we assessed the significance of each non-response frequency class as a covariable, using a step-down analysis approach (Tabachnick \& Fidell 1996). As no significant covariable effects were detected, we present only the independent, univariate models.

We examined relationships between relative subcanopy light levels and various categories of species richness. Similar to our approach above, we first fit a model of light level effects on total species richness (per $100-\mathrm{m}^{2}$ area). In addition, we used similar models with Infrequent Forbs and Infrequent non-Forbs as responses. Each model included two independent variables: ' $\%$ total transmitted light', and 'Block' as a covariable (interaction terms were not significant in each full model, and so were removed in the final model). We used plots from seven of the eight sites, for a total $N=21$. One plot triad was discarded because of difficulties with photo image analysis. Because the species counts of the Infrequent groups were low, we ran each of these models in two ways: (1) as a parametric ANCOVA in PROC GLM, and (2) as a Poisson regression (with block covariable), with log-link function, in PROC GENMOD (SAS). Although the two approaches revealed similar results, residuals from the Poisson models suggested a better model fit, and will be presented here. Individual effects tests were assessed at $\alpha=0.01$.

Multi-response permutation procedures (MRPP) were used to test for differences in species composition and abundances among the three canopy conditions. The MRPP tests the null hypotheses of no differences in mean compositional similarities, and approximate homogeneity of dispersion, relative to samples within a group. We used the full data set, excluding species occurring in single samples (24 plots $\times 212$ species $)$. The distance matrix was calculated as inter-plot Euclidean distances (McCune \& Grace 2002). 'Site' was included as a blocking variable. We tested for overall compositional differences using a single blocked MRPP of three canopy condition groups (A5, A30, P). We investigated the relationship between species compositional variation and sub-canopy light levels, using constrained ordination. Unlike the univariate models in which light levels and species richness were correlated, here we were interested in community variation as a multivariate response, and how compositional variation is related to light as an environmental variable. We 
used Canonical Correspondence Analysis (CCA) because our specific interest was focused on community variation that is related to light conditions only, rather than community structure in general. Additionally, this method allowed us to examine relationships of individual species with light conditions by correlating species scores with constrained axis scores.

We used a matrix of log-transformed species abundance values as our community matrix (21 plots $\times 197$ species). Similar to above, one plot triad was omitted due to difficulty with light measurements. We deleted all species with less than two occurrences because single occurrences contribute only 'noise' to multidimensional ordinations (McCune \& Grace 2002). Many species in the 'rare' category thus were omitted. An 'environmental' vector $(21$ plots $\times 1$ environmental variable) was constructed to represent the total transmitted light variable. Raw transmitted light percentages were transformed using the logit transformation (McCune \& Grace 2002; Tabachnick \& Fidell 1996).

Our application of CCA involved constraining the first axis of the community matrix ordination by a linear regression on the transmitted light variable of the environmental vector. Three axes are interpreted in our CCA; only the first axis is canonical. The site scores were centred and scaled, such that the mean was zero, and variance was one ('biplot scaling', sensu McCune $\&$ Grace 2002). Eigenvalues were computed for each axis, and total variance explained per axis was expressed as the ratio of a specific eigenvalue to the total variance explained in the community matrix. The CCA results were summarized in a biplot of plots and species. Axis scores of plots in the ordination were derived from species data (columns in the main matrix), rather than from the environmental variable.

We used a Monte Carlo randomization test to test the null hypothesis of 'no linear relationship between the community matrix and environmental vector'. Specifically, we assembled the null distribution of canonical eigenvalues obtained from 499 row permutations of the environmental vector. Our observed canonical eigenvalue was compared to this distribution, in an one-tailed test (Legendre \& Legendre 1998).

The relationships between individual species and sub-canopy light levels were quantified via rank correlations, calculated among species scores derived from the community matrix (species scores in 'sample space'), and the scores derived from the linear regression of species on the environmental vector. We identified species with a Kendall's rank correlation coefficient exceeding a critical value $|\tau|>0.37, p<0.01, n=21$ ) as those most related to light conditions. These species are highly correlated with either extreme of the light gradient (high vs. low sub-canopy light conditions).

\section{Results}

A total of 251 vascular plant species were recorded in the subplots at CWP. Large numbers of plant species (82 - 130 per $100-\mathrm{m}^{2}$ subplot) occurred in all subplots, which also contained substantial numbers of each life form. Nonetheless, more than twice as many Forbs as Graminoids or Shrubs were present in subplots at CWP (Table 2).

Overstorey pines influenced CWP ground cover. More species occurred in subplots when the overstorey was absent (A5 and A30) than when the overstorey was present $(\mathrm{P})$, as indicated in Fig. 1A. Both recent and long-term openings contained about $20 \%$ more vascular plant species than similar sized areas beneath overstorey trees. Given that on the average about 100 species occurred in $100-\mathrm{m}^{2}$ subplots, the absence of the overstorey resulted in about 20 more ground-cover species on average present in subplots. A MANOVA of simultaneous responses of species counts by life form revealed significant treatment effects (Table 3). The orthogonal treatment contrast was significant when overstorey absent was compared to overstorey present $\left[\mathrm{H}_{\mathrm{o}}:(\mathrm{A} 5+\mathrm{A} 30) / 2=\right.$ $\mathrm{P}]$; see Table 3. Although subplots open for longer periods of time tended to contain more species, the treatment contrast between recent and older canopy openings $\left(\mathrm{H}_{\mathrm{o}}\right.$ : A5 =A30) was not significant (Table 3).

Responses to overstorey openings were life-form dependent. More Forbs (Fig. 1B) and Graminoids (Fig. 1C), but not Shrubs (Fig. 1D), occurred in subplots with an open overstorey absent than in subplots with an overstorey of Pinus palustris. In univariate models of treatment effects, we included Forb as a covariate for analysis of Graminoids, and vice versa, because there was a significant negative correlation between Forb and Graminoid dependent variables (partial correlation coefficient $=-0.576 ; p=0.024$ ) in the MANOVA model. Other pair-wise correlations were non-significant and thus not included. Univariate models indicated that numbers of species of life forms dominated by long-lived species (both Graminoids and Shrubs) were not different for openings in the overstorey compared to beneath overstorey trees, and that increased numbers of species in subplots without overstorey trees resulted from forbs (Table 3). The orthogonal treatment contrast for overstorey absent compared to present was significant only for forbs. Although subplots open for longer periods of time tended to contain more species of Forbs (Fig. 1B), the contrast between recent and older openings $\left(\mathrm{H}_{\mathrm{o}}\right.$ : A5 = A30) was not significant (Table 3). Univariate models of Forb species counts by frequency class revealed significant treatment effects between overstorey present and absent for Infrequent Forbs (Table 4). Age of overstorey opening did not indicate significant effects. 

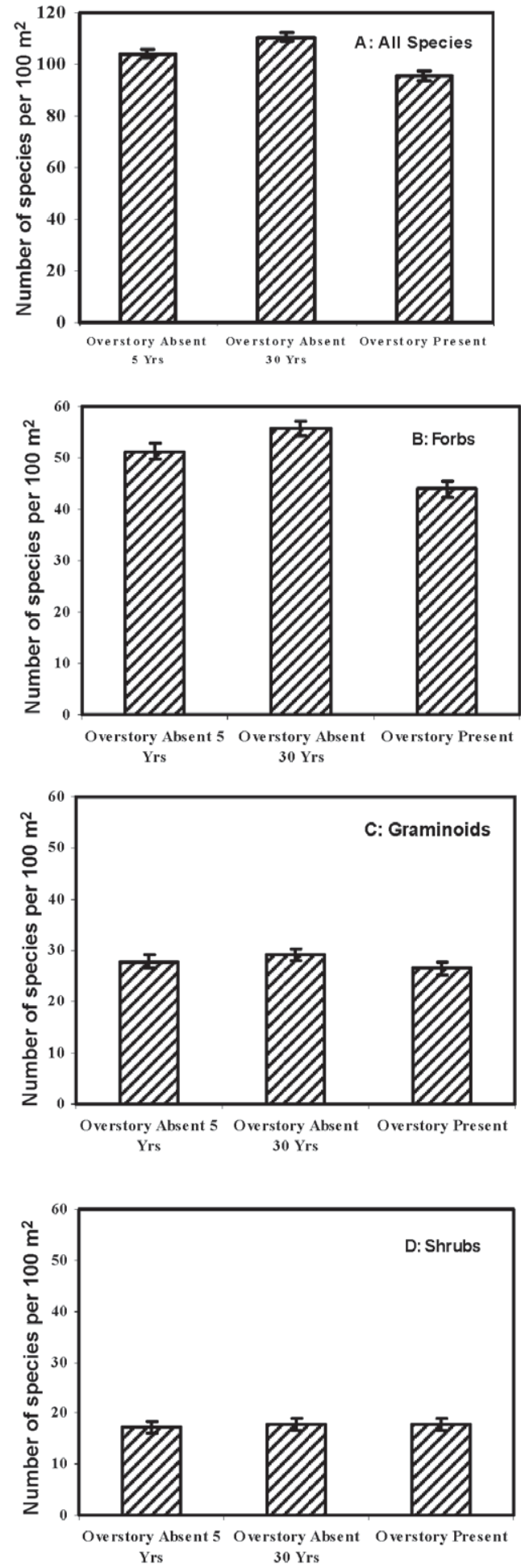

Fig. 1. Numbers of all species (A), Forbs (B), Graminoids (C) and Shrubs (D) in 100- $\mathrm{m}^{2}$ plots at Camp Whispering Pines that have had no canopy for five years, no canopy for at least 30 years, and overstory pines. Vertical bars indicate least square means $( \pm \mathrm{SE})$.
Transmitted light levels measured in the subplots in this study extended over a range of $35-55 \%$ of that expected in the open with no trees present. The lower light levels were similar to those reported for dense overstories in other studies of second-growth Pinus palustris stands, but highest light levels were below those reported in very large gaps in more open stands (e.g. Palik et al. 1997, 2003; McGuire et al. 2001; Battaglia et al. 2002, 2003). Models of relationships between understorey light levels and species richness revealed patterns similar to those produced by the condition of the overstorey. Unlike the experimental treatments, the light-level analyses tested relationships that involved a light continuum. The 'Overstorey present' (P) condition was always ranked the lowest in understorey light levels, but there was no consistent ranking among the 'Overstorey absent' conditions $\left(\mathrm{A}_{5}\right.$ and $\left.\mathrm{A}_{30}\right)$.

Species richness of all species and Infrequent Forbs was positively and linearly related to transmitted light realized at ground level (Fig. 2). An ANCOVA model including block and light level effects explained much of the variance in total species counts $\left(r^{2}=0.66\right)$, with a highly significant effect of percent total transmitted light $(p=0.005)$ and a non-significant effect of blocks ( $p$ $=0.24)$. Similarly strong correlations were obtained between numbers of infrequent forbs and transmitted light levels in Poisson regressions $(p<0.001)$, again
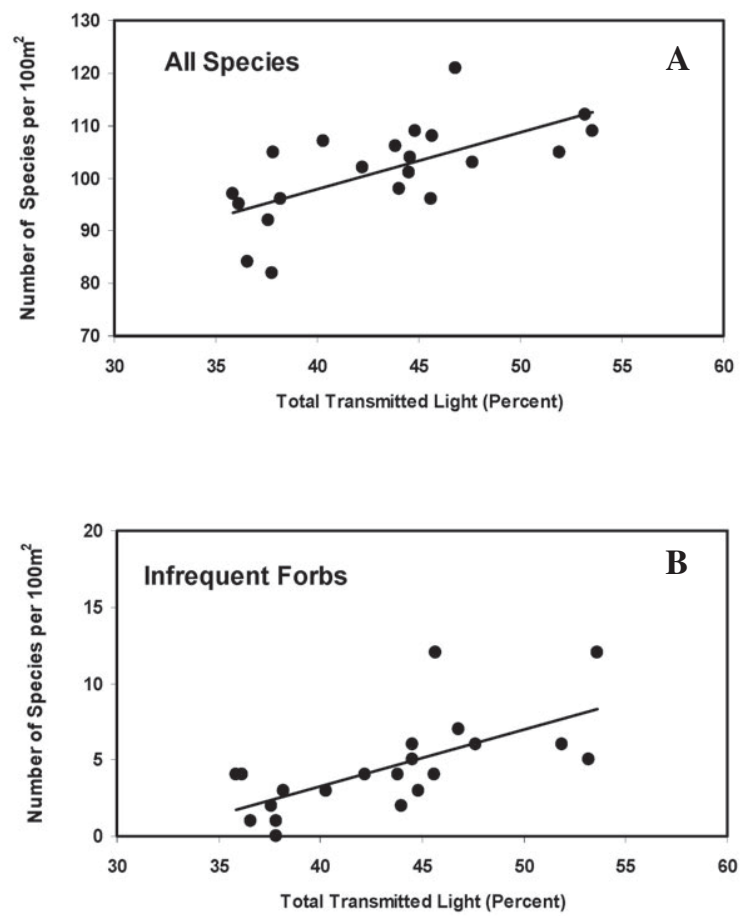

Fig. 2. Relationship between percent total transmitted light and total number of species (A) and numbers of infrequent forbs (B) within 100- $\mathrm{m}^{2}$ subplots at Camp Whispering Pines. 
Table 3. Parametric analyses of effects of overstorey conditions on numbers of species of forbs, graminoids and shrubs. The MANOVA tested simultaneous effects on all three life forms, and post-hoc univariate ANOVA/ANCOVAs were conducted for each life form. Covariates indicated for ANCOVAs under 'Test type'. Two overstorey contrasts are shown for each model: Numbers of species do not differ in plots with and without overstorey pines: $\left[\mathrm{H}_{0}:\left(\mathrm{A}_{5}+\mathrm{A}_{30}\right) / 2=\mathrm{P}\right]$, and numbers of species do not differ in plots with no overstorey pines for five years and for at least 30 years $\left[\mathrm{H}_{0}: \mathrm{A}_{5}=\mathrm{A}_{30}\right]$. Numerator and denominator degrees of freedom are shown in the ' $d f$ ' column. ** indicates significance at $\alpha=0.005$, * indicates non-significant effect.

\begin{tabular}{lllrrr}
\hline Test type & Dependent variable(s) & Effect/Contrast & \multicolumn{1}{c}{$F$} & $d f$ & \multicolumn{1}{c}{$p$} \\
\hline MANOVA & Forb, Graminoid, & $\mathrm{H}_{0}:\left(\mathrm{A}_{5}+\mathrm{A}_{30}\right) / 2=\mathrm{P}$ & 16.29 & 3,12 & $0.0002 * *$ \\
& Shrub & $\mathrm{H}_{0}: \mathrm{A}_{5}=\mathrm{A}_{30}$ & 2.72 & 3,12 & $0.091 *$ \\
ANCOVA & Forb & $\mathrm{H}_{0}:\left(\mathrm{A}_{5}+\mathrm{A}_{30}\right) / 2=\mathrm{P}$ & 42.18 & 1,13 & $0.0001 * *$ \\
W/ Gram COV & & $\mathrm{H}_{0}: \mathrm{A}_{5}=\mathrm{A}_{30}$ & 8.065 & 1,13 & $0.014 *$ \\
ANCOVA & \multirow{2}{*}{ Graminoid } & $\mathrm{H}_{0}:\left(\mathrm{A}_{5}+\mathrm{A}_{30}\right) / 2=\mathrm{P}$ & 9.13 & 1,13 & $0.009 *$ \\
W/ Forb COV & & $\mathrm{H}_{0}: \mathrm{A}_{5}=\mathrm{A}_{30}$ & 3.93 & 1,13 & $0.068 *$ \\
ANOVA & \multirow{2}{*}{ Shrub } & $\mathrm{H}_{0}:\left(\mathrm{A}_{5}+\mathrm{A}_{30}\right) / 2=\mathrm{P}$ & 0.01 & 1,14 & $0.919 *$ \\
& & $\mathrm{H}_{0}: \mathrm{A}_{5}=\mathrm{A}_{30}$ & 0.29 & 1,14 & $0.598 *$ \\
\hline
\end{tabular}

with a non-significant effect of blocks $(p=0.03)$. Analysis of numbers of infrequent non-forbs revealed no significant correlations with percent total transmitted light.

Community structure, as reflected in species composition and abundances, appeared to vary weakly with canopy condition. First, an overall difference in community structure was detected among the three canopy conditions (Blocked MRPP; $p=0.002$ ). Nonetheless, because MRPP detects differences in both mean similarities and sample dispersions, we cannot conclude group differences are attributable solely to differences in species composition and abundance. Second, we detected evidence that some variation in community structure might be related to sub-canopy light levels. The first canonical axis of the constrained ordination represented a linear regression of transmitted light on the community matrix. Although the Monte Carlo test indicated weak significance in the strength of the canonical axis eigenvalue (axis 1 eigenvalue $=0.07$, Monte Carlo test $p=0.04$ ), this axis represents only small proportion of 'variation explained' (6.9\%; Table $5)$. Some separation of plots by canopy condition category is apparent in the CCA biplot, although a wide breadth of light levels among plots of the $\mathrm{A}_{30}$ category is evident (Fig. 3).

In total 38 species were significantly correlated with canonical axis scores (Table 6). Correlations were negative for 30 species, indicating a positive correlation with transmitted light levels (Table 6). These helophytic species all belong to the Forb and Graminoid life form categories, and $>70 \%$ were species with at least a short-term seed bank. Because we deleted singleton occurrences prior to ordination, many species in the Infrequent class were not included in this analysis. Most species correlated with light conditions were in the Intermediate class. Only eight species were positively correlated with low light conditions. Of the Forb types, most were herbaceous vines, indicated as Forb/Liana in Table 6. A single shrub species, Viburnum dentatum, was highly correlated with low light conditions.

Table 4. MANOVA and subsequent univariate ANOVA analyses of effects of overstorey conditions on numbers of species of Common, Intermediate, and Infrequent forbs. Two overstorey contrasts are shown for each model: Numbers of species do not differ in plots with and without overstorey pines: $\left[\mathrm{H}_{0}:\left(\mathrm{A}_{5}+\mathrm{A}_{30}\right) / 2=\mathrm{P}\right]$, and numbers of species do not differ in plots with no overstory pines for five years and for at least 30 years $\left[\mathrm{A}_{5}=\mathrm{A}_{30}\right]$. Numerator and denominator degrees of freedom are shown in ' $d f$ ' column. ** indicates significance at $\alpha=0.005$. $*$ indicates non-significant effect.

\begin{tabular}{|c|c|c|c|c|c|}
\hline Test type & Dependent variable(s) & Effect/Contrast & $F$ & $d f$ & $p$ \\
\hline MANOVA & $\begin{array}{l}\text { Common, Intermediate, } \\
\text { Infrequent }\end{array}$ & $\begin{array}{l}\mathrm{H}_{0}:\left(\mathrm{A}_{5}+\mathrm{A}_{30}\right) / 2=\mathrm{P} \\
\mathrm{H}_{0}: \mathrm{A}_{5}=\mathrm{A}_{30}\end{array}$ & $\begin{array}{r}12.83 \\
2.64\end{array}$ & $\begin{array}{l}3,12 \\
3,12\end{array}$ & $\begin{array}{c}0.0005 * * \\
0.097 *\end{array}$ \\
\hline ANOVA & Common & $\begin{array}{l}\mathrm{H}_{0}:\left(\mathrm{A}_{5}+\mathrm{A}_{30}\right) / 2=\mathrm{P} \\
\mathrm{H}_{0}: \mathrm{A}_{5}=\mathrm{A}_{30}\end{array}$ & $\begin{array}{l}4.02 \\
0.01\end{array}$ & $\begin{array}{l}1,14 \\
1,14\end{array}$ & $\begin{array}{l}0.064 * \\
0.950 *\end{array}$ \\
\hline ANOVA & Intermediate & $\begin{array}{l}\mathrm{H}_{0}:\left(\mathrm{A}_{5}+\mathrm{A}_{30}\right) / 2=\mathrm{P} \\
\mathrm{H}_{0}: \mathrm{A}_{5}=\mathrm{A}_{30}\end{array}$ & $\begin{array}{l}5.44 \\
3.66\end{array}$ & $\begin{array}{l}1,14 \\
1,14\end{array}$ & $\begin{array}{l}0.035 * \\
0.076 *\end{array}$ \\
\hline ANOVA & Infrequent & $\begin{array}{l}\mathrm{H}_{0}:\left(\mathrm{A}_{5}+\mathrm{A}_{30}\right) / 2=\mathrm{P} \\
\mathrm{H}_{0}: \mathrm{A}_{5}=\mathrm{A}_{30}\end{array}$ & $\begin{array}{r}22.58 \\
6.10\end{array}$ & $\begin{array}{l}1,14 \\
1,14\end{array}$ & $\begin{array}{c}0.0003 * * \\
0.02 *\end{array}$ \\
\hline
\end{tabular}




\section{Discussion and Conclusions}

Our experimental study demonstrated that the overstorey influences biodiversity in the ground cover of pine savannas. Removal of the overstorey results in approximately a $20 \%$ increase in numbers of species within five years, and those increases appear to be maintained over several decades. Many of these 'early' species (sensu Platt \& Connell 2003) added after removal of the overstorey are not present as actively growing life cycle stages when overstorey trees are present. Instead, these are 'seed bank species' that break dormancy following disturbance. These species, however, are not transient fugitives, but are persistent aboveground components of the ground cover as long as the overstorey remains open and fires remove above-ground plant biomass and litter frequently.

'Seed bank species' include both monocarpic and polycarpic heliophytic species whose occurrences were positively correlated with transmitted light levels. The monocarpic forbs comprise $28 \%$ of forb species and $18 \%$ of all species recorded in the subplots in this study. These species include annuals, e.g.:

$\begin{array}{ll}\text { Ambrosia artemisiifolia } & \begin{array}{l}\text { Drosera brevifolia } \\ \text { Hedyotis crassifolia }\end{array} \\ \begin{array}{l}\text { Mitreola sessifolia } \\ \text { Trachostema dichotomum }\end{array} & \text { Sabatia angularis } \\ \text { and biennials, e.g.: } & \\ \text { Cirsium horridulum } & \text { Helenium flexuosum } \\ \text { Helenium brevifolium } & \text { Polyanthes virginica }\end{array}$

Further, several short-lived perennial forbs also have a seed bank persistent for at least several years, e.g.:

$\begin{array}{ll}\text { Galium uniflorum } & \text { Gratiola pilosa } \\ \text { Hieracium gronovii } & \text { Hypericum crux-andreae } \\ \text { Hypericum setosum } & \text { Lechea minor } \\ \text { Lobelia puberula } & \text { Pluchea foetida } \\ \text { Scutellaria integrifolia. } & \end{array}$

In addition to forbs, some small-stature graminoids also have at least a short-term seed bank; these include annuals: and short-lived perennials:

$\begin{array}{ll}\text { Digitaria violescens, } & \text { Agrostis perennans } \\ \text { Fimbrystylis decipiens } & \text { Dichanthelium } \mathrm{spp} . \\ \text { Panicum verrucosum } & \text { Fimbristylis puberula }\end{array}$

The 'seed bank species' at Camp Whispering Pines typically germinate during the growing season after fires. The timing of germination of these species spans the entire growing season, from shortly after the first post-fire summer rains in May/June to the onset of late fall/early winter rains in November/December (see Olson \& Platt 1995 for the seasonal patterns of rains in Gulf coast pine savannas). We have frequently noted germinating seedlings of these species in open spaces among large-stature clonal Graminoids, Forbs and Shrubs (also see Brewer 1999c, 2001). The seed bank species occur
Table 5. Summary results of Canonical Correspondence Analysis of main species matrix, and environmental vector of subcanopy light levels. Eigenvalues, percent of total explained variance (of species data), and cumulative percent variance, listed for each ordination axis. * Axis 1 is constrained by a linear regression on light levels. The correlation coefficient (species scores vs. predicted scores from regression) is shown for the canonical axis.

\begin{tabular}{lccc}
\hline Parameter & Axis 1* & Axis 2 & Axis 3 \\
\hline Eigenvalue & 0.07 & 0.125 & 0.111 \\
Percent variance & 6.9 & 12.3 & 10.9 \\
Cumulative \% variance & 6.9 & 19.2 & 30.2 \\
Pearson correlation & 0.87 & 0 & 0 \\
\hline
\end{tabular}

in both recently generated and older openings in the overstorey, indicating that local sites may be re-colonized after successive fires as long as there is no overstorey and fires occur frequently. Thus, increased light from openings in the overstorey appear more important for germination of these species than soil disturbance. Seed bank species have been noted as abundant in some grasslands (e.g. Knops et al. 1995; Freeman 1998), as well as many, but not all pine savannas (e.g. contrast Bridges \& Orzell 1998; Brewer 1998a, b, 1999a, b, DeCoster et al. 1999; this study; with Kirkman et al. 2001 and Simkin et al. 2001).

Fires transiently open the ground-cover canopy (Platt 1999). Frequent fires might increase the likelihood that species with short-term seed banks in the soil would be present locally within the ground cover in areas without an overstorey (also see Brown \& Peet 2003). Frequent fires also have been suggested to ameliorate competition for light until dominant grasses and shrubs regrow and litter accumulates (Walker \& Peet 1983; Brewer 2003; Glitzenstein et al.2003). Reduced effects of dominant species, especially shrubs and grasses, have been hypothesized to generate a 'window for recruitment', potentially increasing local numbers of herbaceous species in the ground cover if environmental conditions are conducive for seedling establishment (Brewer \& Platt 1994a; Brockway \& Lewis 1997; Brewer 1998a, 1999a-c, 2001; Sparks et al. 1998; Kirkman et al. 2001). For example, ca. $20 \%$ increases occurred in the numbers of species in Everglades rockland savanna when average fire frequency was increased from once every 5 years to once every 2.5 years (DeCoster et al. 1999). Nonetheless, disagreement persists regarding the extent to which opening the ground-cover canopy (either by fire or soil disturbance) should enhance local smallscale biodiversity in pine savannas (compare Streng et al. 1993; Brewer et al. 1996; Sparks et al. 1998; with Kirkman et al. 2001, Simkin et al. 2001). 
Table 6. List of species significantly correlated with the gradient in transmitted light. Species scores are correlated with those of the canonical axis (constrained on light levels). Species with Kendall's $\tau$ rank correlation $>0.37$ or $<-0.37$ are displayed ( $p<0.01$ per correlation). 'Code' denotes species, and is displayed in Fig. ' Life form' identifies general life form category of species. Species designations as seed bank (s) or dispersive (d) are based on field observations over the past decade. 'Light' indicates the region of the light gradient with which species is correlated.

\begin{tabular}{|c|c|c|c|c|c|}
\hline Code & Species & Life form & Guild & Light & Kendall's $\tau$ \\
\hline HYSET & Hypericum setosum & forb & $\mathrm{s}$ & high & -0.641 \\
\hline PAVE & Panicum verrucosum & graminoid & $\mathrm{s}$ & high & -0.622 \\
\hline MISE & Mitreola sessifolia & forb & $\mathrm{s}$ & high & -0.578 \\
\hline DIDI & Dichanthelium acuminatum & graminoid & $\mathrm{s}$ & high & -0.558 \\
\hline HYCR & Hypericum crux-andreae & forb & $\mathrm{s}$ & high & -0.535 \\
\hline PLFO & Pluchea foetida & forb & $\mathrm{s}$ & high & -0.534 \\
\hline RHSP & Rhynchospora globularis & graminoid & $\mathrm{s}$ & high & -0.503 \\
\hline DIST & Dichanthelium strigosum & graminoid & $\mathrm{s}$ & high & -0.499 \\
\hline LEMI & Lechea minor & forb & $\mathrm{s}$ & high & -0.498 \\
\hline LIME & Linum medium & forb & $\mathrm{s}$ & high & -0.497 \\
\hline HEAN & Helianthus angustifolius & forb & $\mathrm{d}$ & high & -0.478 \\
\hline GRPI & Gratiola pilosa & forb & $\mathrm{s}$ & high & -0.466 \\
\hline FIPU & Fimbristylis puberula & graminoid & $\mathrm{s}$ & high & -0.465 \\
\hline SORU & Solidago rugosa & forb & d & high & -0.463 \\
\hline MYCE & Morella cerifera & shrub & d & high & -0.453 \\
\hline LOPU & Lobelia puberula & forb & $\mathrm{s}$ & high & -0.452 \\
\hline DIGVI & Digitaria violascens & graminoid & $\mathrm{s}$ & high & -0.45 \\
\hline SCPA & Scleria pauciflora & graminoid & $\mathrm{s}$ & high & -0.439 \\
\hline SCIN & Scutellaria integrifolia & forb & $\mathrm{s}$ & high & -0.436 \\
\hline HEBR & Helenium brevifolium & forb & $\mathrm{s}$ & high & -0.436 \\
\hline RUTR & Rubus trivialis & liana & $\mathrm{d}$ & high & -0.433 \\
\hline DRBR & Drosera brevifolia & forb & $\mathrm{s}$ & high & -0.432 \\
\hline BODI & Boltonia diffusa & forb & $\mathrm{d}$ & high & -0.427 \\
\hline SCSC & Schizachyrium scoparium & graminoid & $\mathrm{d}$ & high & -0.415 \\
\hline COLA & Coreopsis lanceolata & forb & $\mathrm{s}$ & high & -0.411 \\
\hline GAUN & Galium uniflorum & forb & $\mathrm{s}$ & high & -0.409 \\
\hline RHSP. & Rhynchospora globularis & graminoid & $\mathrm{s}$ & high & -0.406 \\
\hline EURO & Eupatorium rotundifolium & forb & d & high & -0.398 \\
\hline HECR & Hedyotis crassifolia & forb & $\mathrm{s}$ & high & -0.381 \\
\hline EULEU & Eupatorium leucolepis & forb & $\mathrm{d}$ & high & -0.371 \\
\hline VIDE & Viburnum dentatum & shrub & $\mathrm{d}$ & low & 0.529 \\
\hline SMSM & Smilax smallii & forb/liana & $\mathrm{d}$ & low & 0.406 \\
\hline GAVO & Galactia volubilis & forb/liana & $\mathrm{d}$ & low & 0.392 \\
\hline DIRA & Dichanthelium ravenellii & graminoid & $\mathrm{d}$ & low & 0.385 \\
\hline SMRO & Smilax rotundifolia & forb/liana & $\mathrm{d}$ & low & 0.378 \\
\hline TRDIF & Trachelospermum difforme & forb/liana & $\mathrm{d}$ & low & 0.374 \\
\hline DECI & Desmodium ciliare & forb & $\mathrm{d}$ & low & 0.371 \\
\hline ASCCO & Asclepias connivens & forb & $\mathrm{d}$ & low & 0.368 \\
\hline
\end{tabular}

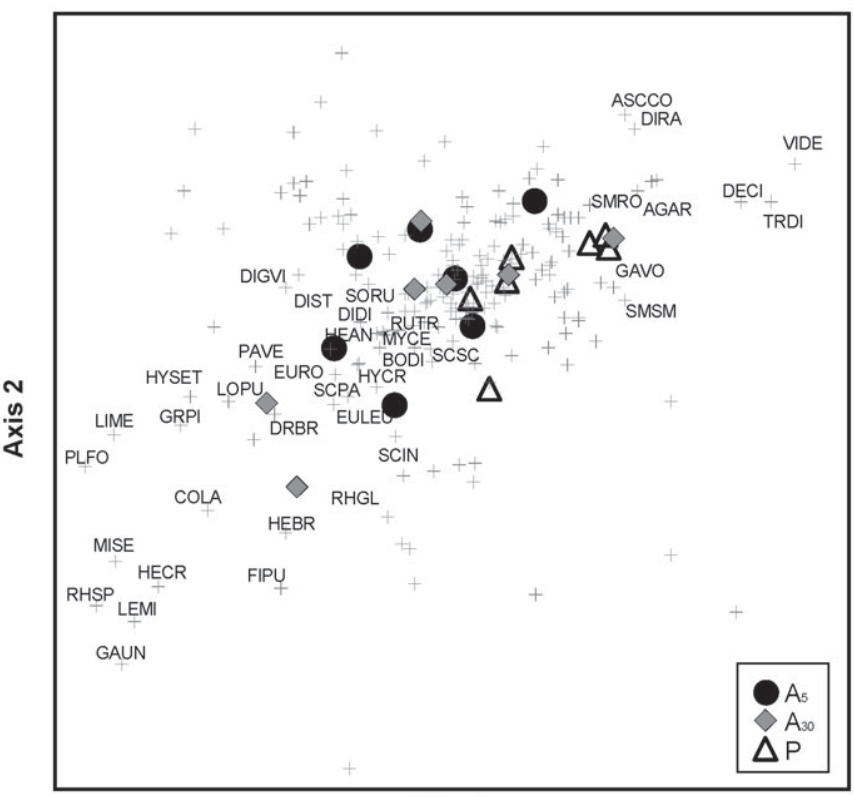

Axis 1
Fig. 3. Canonical Correspondence Analysis ordination biplot of plots (large symbols) and species (small symbols). First two axes shown, of a three dimensional solution. The first axis is canonical, constrained by a linear regression on transformed sub-canopy light levels (see text). Different large symbols denote canopy conditions $\left(\mathrm{A}_{5}=\right.$ recent openings, $\mathrm{A}_{30}=$ older openings, and $\mathrm{P}=$ closed canopy). Small ticks with species code indicate identity and position of species with high correlation with the first canonical axis. See Table 6 for list of codes. 
We propose that three environmental conditions influence the effects of opening the ground-cover canopy via fire on local biodiversity. These include the presence/ absence of an overstorey of pines, numbers of seed bank species in the local species pool, and environmental conditions that influence germination and growth of these small-stature species. Frequent fires transiently reduce sizes of the large graminoids and shrubs and open interstitial space in all pine savannas that have been studied, regardless of whether dominant species are caespitose or rhizomatous (cf. Kirkman et al. 2001). Increased transmitted light, as indicated by our study, is associated with larger numbers of less abundant, small-stature forbs. Nonetheless, increased numbers of species in the ground cover following openings of the overstorey and ground cover appear to occur only in mesic- hydric savannas, suggesting that effects of opening of the ground cover may be dependent on species pool and resources - contrast this study, Walker \& Peet (1983) and Brewer (1998b) with Kirkman et al. (2001) and Simkin et al. (2001). Thus restoration involving removal of overstorey pines is most likely to benefit the ground cover in frequently burned sites that contain seed bank species that can respond to increased light levels.

Restoration and management concepts in frequently burned pine savannas with a large pool of 'seed bank species' should consider the spatial distribution of openings designed to enhance ground-cover biodiversity. We propose that restoration of Pinus palustris savannas containing abundant small-stature, seed bank species involve planned openings that incorporate concepts of dispersal limitation. Dispersal of most seed bank species occurs only very short distances. As a result, local spatial heterogeneity in species distributions may be considerable. We suggest that smaller openings that are scattered across the landscape will produce responses by more of these often rare species than fewer, but larger openings or smaller openings that are concentrated in restricted areas.

Acknowledgements. This study was supported by a nongovernment organization grant to the Girl Scout Council of Southeastern Louisiana from Environmental Defense. The Girl Scout Council of Southeastern Louisiana, and especially Larry Ehrlich, provided logistical support for this project. We thank Larry Ehrlich for conducting the prescribed fires in ways that mimicked lightning fires while protecting camping structures at Camp Whispering Pines. Billy Platt, Maggie Platt, Jarrod Thaxton, Virginia Thaxton and Heather Passmore helped us set up the plots. Maggie Platt, Jarrod and Virginia Thaxton, Heather Passmore, Rae Crandall and Kyle Harms provided useful comments on this manuscript. We also thank Toby, Junior, Sadie, Chap, Kimber, and Molly for their companionship during the collection of field data.

\section{References}

Baldwin, A.H., Egnotovich, M.S., Ford, M.A. \& Platt, W.J. 2001. Regeneration in fringe mangrove forests damaged by Hurricane Andrew. Plant Ecol. 57: 151-164.

Battaglia, M.A., Pu, M., Palik, B. \& Mitchell, R.J. 2002. The effect of spatially variable overstorey on the understory light environment of an open-canopied long leaf pine forest. Can. J. For. Res. 32: 1984-1991.

Battaglia, M.A., Mitchell, R.J., Pu, M. \& Pecot, S.D. 2003. Light transmittance estimates in a longleaf pine woodland. For. Sci. 49: 1-11.

Beckage, B.\& Stout, I.J. 2000. The effects of repeated burning on species richness in Florida sandhills: A Test of the Intermediate Disturbance Hypothesis. J. Veg. Sci. 11: 113-122.

Beckage, B., Platt, W.J. \& Panko, B. 2005. A climate-based approach to the restoration of fire dependent ecosystems. Restor. Ecol. 13: 429-431.

Brewer, J.S. 1998a. Effects of competition and litter on a carnivorous plant, Drosera capillaris, Droseraceae. Am. J. Bot. 85: 1592-1596.

Brewer, J.S. 1998b. Patterns of plant species richness in a wet slash-pine (Pinus elliottii) savanna. J. Torrey Bot. Soc. 125: 216-224.

Brewer, J.S. 1999a. Effects of competition, litter, and disturbances on an annual carnivorous plant (Utricularia juncea). Plant Ecol. 140: 159-165.

Brewer, J.S. 1999b. Effects of fire, competition, and soil disturbance on regeneration of a carnivorous plant (Drosera capillaris). Am. Midl. Nat. 141: 28-42.

Brewer, J.S. 1999c. Short-term effects of fire and competition on growth and plasticity of the yellow pitcher plant, Sarracenia alata (Sarraceniaceae). Am. J. Bot. 86: 12641271.

Brewer, J.S. 2001. A demographic analysis of fire-stimulated seedling establishment in Sarracenia alata (Sarraceniaceae). Am. J. Bot. 88: 1250-1257.

Brewer, J.S. 2003. Why don't carnivorous pitcher plants compete with non-carnivorous plant for nutrients? Ecology 84: 451-462.

Brewer, J.S. \& Platt, W.J. 1994a. Effects of fire season and herbivory on reproductive success in a clonal forb, Pityopsis graminifolia (Michx.) Nutt. J. Ecol. 82: 665-675.

Brewer, J.S. \& Platt, W.J. 1994b. Effects of fire season and soil fertility on clonal growth in a pyrophilic forb, Pityopsis graminifolia (Asteraceae). Am. J. Bot. 81: 805-814.

Brewer, J.S., Platt, W.J., Glitzenstein, J.S. \& Streng, D.R. 1996. Effects of fire-generated gaps on growth and reproduction of golden aster (Pityopsis graminifolia). Bull. Torrey Bot. Club 123: 295-303.

Bridges, E.L. \& Orzell, S.L. 1989. Longleaf pine communities of the west Gulf coastal plain. Nat. Areas J. 9: 246-263.

Brockway, D.G. \& Lewis, C.E. 1997. Long-term effects of dormant-season prescribed fire on plant community diversity, structure, and productivity in a longleaf pine wiregrass ecosystem. For. Ecol. Manage. 96: 167-183.

Brockway, D.G. \& Outcalt, K.W. 1998. Gap-phase regeneration in longleaf pine wiregrass ecosystems. For. Ecol. 
Manage. 106: 125-139.

Brockway, D.G., Outcalt, K.W. \& Wilkins, R.N. 1998. Restoring longleaf pine wiregrass ecosystems: plant cover, diversity, and biomass following low-rate hexazinone application on Florida sandhills. For. Ecol. Manage.103: 159-175.

Brown, R.L. \& Peet, R.K. 2003. Diversity and invasibility of southern Appalachian plant communities. Ecology 84: 3239.

Collins, B.S., Dunne, K.P. \& Pickett, S.T.A. 1985. Responses of forest herbs to canopy gaps. In: Pickett, S.T.A. \& White, P.S. (eds.) The ecology of natural disturbance and patch dynamics, pp. 217-234. Academic Press, New York, NY, US.

DeCoster, J., Platt, W.J. \& Riley, S.A. 1999. Pine savannas of Everglades National Park: An endangered ecosystem. In: Jones, D.T. \& Gamble, B.W. (eds.) Florida's Garden of Good and Evil, pp. 81-88. Proceedings of the 1998 Joint Symposium of the Florida Exotic Pest Plant Council and the Florida Native Plant Society. South Florida Water Management District, West Palm Beach, FL, US.

Doren, R.F., Platt, W.J. \& Whiteaker, L.D. 1993. Density and size structure of slash pine stands in the everglades region of south Florida. For. Ecol. Manage. 59: 295-311.

Drewa, P.B., Platt, W.J. \& Moser, E.B. 2002a. Community structure along elevation gradients in southeastern longleaf pine savannas. Plant Ecol. 160: 61-78.

Drewa, P.B., Platt, W.J.\& Moser, E.B. 2002b. Fire effects on resprouting of shrubs in southeastern longleaf pine savannas. Ecology 83: 755-767.

Engelbrecht, B.M.J. \& Herz, H.M. 2001. Evaluation of different methods to estimate understory light conditions in tropical forests. J. Trop. Ecol. 17: 207-224.

Ferguson, B.G., Boucher, D.H., Pizzi, M. \& Rivera, C. 1995. Recruitment and decay of a pulse of Cecropia in Nicaraguan rain forest damaged by Hurricane Joan: relation to mutualism with Azteca ants. Biotropica 27: 455-460.

Folkerts, G.W., Deyrup, M.A. \& Sisson, C.D. 1993. Arthropods associated with xeric longleaf pine habitats in the southeastern United States. Proceedings Tall Timbers Fire Ecology Conference 18: 159-192.

Frazer, G.W., Canham, C.D. \& Lertzman, K.P. 1999. Gap Light Analyzer, Version 2.0: Imaging software to extract canopy structure and gap light transmission indices from true-color fisheye photographs. User's manual and program documentation. Simon Fraser University. Burnaby, British Columbia, and the Institute of Ecosystem Studies, Millbrook, New York, NY, US.

Freeman, C.C. 1998. The flora of Konza Prairie: a historical review and contemporary patterns. In: Knapp, A.K., Briggs, J.M., Hartnett, D.C. \& Collins, S.L. (eds.) Grassland dynamics: long-term ecological research in tallgrass prairie, pp. 69-80. Oxford University Press, New York, NY, US.

Gilliam, F.S. \& Platt, W.J. 1999. Effects of long-term fire exclusion on tree species composition and structure in an old-growth Pinus palustris (longleaf pine) forest. Plant Ecology 140: 15-26.

Gilliam, F.S. \& Platt, W.J. 2006. Conservation and restoration of the Pinus palustris ecosystem. Appl. Veg. Sci. 9: 5-10.

Gilliam, F.S., Yurish, B.M. \& Goodwin, L.M. 1993. Community composition of an old growth longleaf pine forest: relationship to soil texture. Bull. Torrey Bot. Club 120: 287-294.

Glitzenstein, J.S., Platt, W.J. \& Streng, D.R. 1995. Effects of fire regime and habitat on tree dynamics in north Florida longleaf pine savannas. Ecol. Monogr. 65: 441-476.

Glitzenstein, J.S., Streng, D.R. \& Wade, D.D. 2003. Fire frequency effects on longleaf pine (Pinus palustris $\mathrm{P}$. Miller) vegetation in South Carolina and northeast Florida, USA. Nat. Areas J. 23: 22-37.

Grace, S.L. \& Platt, W.J. 1995a. Effects of adult tree density and fire on the demography of pre-grass stage juvenile longleaf pine (Pinus palustris Mill.). J. Ecol. 95: 75-86.

Grace, S.L. \& Platt, W.J. 1995b. Neighborhood effects on juveniles in an old-growth stand of longleaf pine (Pinus palustris Mill.). Oikos 72: 99-105.

Guyer, C. \& Bailey, M.A. 1993. Amphibians and reptiles of longleaf pine communities. Proceedings Tall Timbers Fire Ecology Conference 18: 139-158.

Guzmán-Grajales, S.M. \& Walker, L.R. 1991. Differential seedling responses to litter after Hurricane Hugo in the Luquillo experimental forest, Puerto Rico. Biotropica 23: 407-413.

Harrington, T. \& Edwards, E.M. 1999. Understory vegetation, resource availability, and litterfall responses to pine thinning and woody vegetation control in longleaf pine plantations. Can. J. For. Res. 29: 1055-1064.

Hjerpe, J., Hedenås, H. \& Elmqvist, T. 2001. Tropical rain forest recovery from cyclone damage and fire in Samoa. Biotropica 33: 249-259.

Horvitz, C.C. \& Schemske, D.W. 1986. Seed dispersal and environmental heterogeneity in a neotropical herb: a model of population and patch dynamics. In: Estrada, A. \& Fleming, T.H. (eds.) Frugivores and seed dispersal, pp. 170-186. Junk, Dordrecht, NL.

James, F.C., Hess, C.A. \& Kufrin, D. 1997. Species-centered environmental analysis: indirect effects of fire history on red-cockaded woodpeckers. Ecol. Appl. 7: 118-129.

Jones, R.H., Mitchell, R.J., Stevens, G.N. \& Pecot, S.D. 2003. Controls of fine root dynamics across a gradient of gap sizes in a pine woodland. Ecosyst. Ecol. 134: 132-143.

Kirkman, L.K., Mitchell, R.J., Helton, R.C. \& Drew, M.B. 2001. Productivity and species richness across an environmental gradient in a fire-dependent ecosystem. Am. J. Bot. 88: 2119-2128.

Knops, J.M.H., Griffin, J.R. \& Royalty, A.C. 1995. Introduced and native plants of the Hastings Reservation, central coastal California: a comparison. Biol. Conserv. 71: 115-123.

Kush, J.S., Meldahl, R.S. \& Boyer, W.D. 1999. Understory plant community response after 23 years of hardwood control treatments in natural longleaf pine (Pinus palustris) forests. Can. J. For. Res. 29: 1047-1054.

Legendre,P.\& Legendre,L. 1998. Numerical ecology. Elsevier. Amsterdam, NL.

Martinsen, G.D., Cushman, J.H. \& Whitham, T.G. 1990. Impact of pocket gopher disturbance on plant species 
diversity in a shortgrass prairie community. Oecologia 83 : 132-138.

Matthews, J.D. 1991. Silvicultural Systems. Oxford University Press, Oxford, UK.

McCune, B. \& Grace, J.B. 2002. Analysis of ecological communities. MjM Software, Gleneden Beach, OR, US.

McDaniel, D. 1990. Soil survey of Tangipahoa Parish, Louisiana. U.S. Soil Conservation Service, Washington, DC, US.

McGuire, J.P., Mitchell, R.J., Moser, E.B., Pecot, S.D., Gjerstad, D.H. \& Hedman, C.W. 2001. Gaps in a gappy forest: plant resources, longleaf pine regeneration, and understory response to tree removal in longleaf pine savannas. Can. J. For. Res. 31: 765-778.

McIntyre, S., Lavorel, S. \& Tremont, R.M. 1995. Plant life history attributes: their relationship to disturbance response in herbaceous vegetation. J. Ecol. 83: 31-44.

Means, D.B. 1996. Longleaf pine forests, going, going, ... In: Davis, M.E. (ed.) Eastern old-growth forests, pp. 210229. Island Press, Washington, DC, US.

Means, D.B. \& Grow, G.O. 1985. The endangered longleaf pine community. ENFO, September, 1-12.

Mulligan, M.K., Kirkman,L. K.\& Mitchell, R.J.2002. Aristida beyrichiana (wiregrass) establishment and recruitment: implications for restoration. Rest. Ecol. 10: 68-76.

Noel, J.M., Platt, W.J. \& Moser, E.B. 1998. Structural characteristics of old- and second-growth stands of longleaf pine (Pinus palustris) in the Gulf coastal region of the U.S.A. Conserv. Biol. 12: 533-548.

Olson, M.S.\& Platt, W.J. 1995. Effects of habitat and growing season fires on resprouting of shrubs in longleaf pine savannas. Vegetatio 119: 101-118.

Palik, B.J., Mitchell, R.J., Houseal, G. \& Pederson, N. 1997. Effects of canopy structure on resource availability and seedling responses in a longleaf pine ecosystem. Can.J. For. Res. 27: 1458-1464.

Palik, B., Mitchell, R.J., Pecot, S., Battaglia, M. \& Pu, M. 2003. Spatial distribution of overstorey retention influences resources and growth of longleaf pine seedlings. Ecol. Appl. 13: 674-686.

Peet, R.K. \& Allard, D.J. 1993. Longleaf pine vegetation of the southern Atlantic and eastern Gulf coast regions: a preliminary classification. Proceedings Tall Timbers Fire Ecology Conference 18: 45-81.

Platt, W.J. 1975. The colonization and formation of equilibrium plant species associations on badger disturbances in a tall-grass prairie. Ecol. Monogr. 45: 285-305.

Platt, W.J. 1976. The natural history of a fugitive prairie plant (Mirabilis hirsuta (Pursh) MacM.). Oecologia 22: 399409.

Platt, W.J. 1999. Southeastern pine savannas. In: Anderson, R.C., Fralish, J.S.\& Baskin, J. (eds.) The savanna, barren, and rock outcrop communities of North America, pp. 2351. Cambridge University Press, Cambridge, UK.

Platt, W.J. \& Connell, J.H. 2003. Natural disturbances and directional replacement of species. Ecol. Monogr. 73: 507-522.

Platt, W.J. \& Rathbun, S.L. 1993. Dynamics of an old-growth longleaf pine population. Proceedings Tall Timbers Fire
Ecology Conference 18: 275-297.

Platt, W.J., Evans, G.W. \& Rathbun, S.L. 1988. The population dynamics of a long-lived conifer (Pinus palustris). Am. Nat. 131: 491-525.

Platt, W.J., Glitzenstein, J.S. \& Streng, D.R. 1991. Evaluating pyrogenicity and its effects on vegetation in longleaf pine savannas. Proceedings Tall Timbers Fire Ecology Conference 17: 143-161.

Platt, W.J., Doren, R.F. \& Armentano, T. 2000. Effects of Hurricane Andrew on stands of slash pine (Pinus elliottii var. densa) in the everglades region of south Florida (USA). Plant Ecology 146: 43-60.

Platt, W.J., Beckage, B., Doren, R.F. \& Slater, H.H. 2002. Interactions of large-scale disturbances: prior fire regimes and hurricane mortality of savanna pines. Ecology 83: 1566-1572.

Poulson, T.L. \& Platt, W.J. 1989. Gap light regimes influence canopy tree diversity. Ecology 70: 553-555.

Poulson, T.L. \& Platt, W.J. 1996. Replacement patterns of beech and sugar maple in Warren Woods, Michigan. Ecology 77: 1234-1253.

Rebertus, A.J., Williamson, G.B. \& Moser, E.B. 1989a. Fireinduced changes in Quercus laevis spatial pattern in Florida sandhills. J. Ecol. 77: 638-650.

Rebertus, A.J., Williamson, G.B. \& Moser, E.B. 1989 b. Longleaf pine pyrogenicity and turkey oak mortality in Florida xeric sandhills. Ecology 70: 60-70.

Rebertus, A.J., Williamson, G.B. \& Platt, W.J. 1993. Impacts of temporal variation in fire regime on savanna oaks and pines. Proceedings Tall Timbers Fire Ecology Conference 18: 215-225.

Schmitz, M., Platt, W.J. \& DeCoster, J. 2002. Substrate heterogeneity and numbers of plant species in Everglades savannas (Florida, USA). Plant Ecol. 160: 137-148.

Simkin, S.M., Michener, W.K. \& Wyatt, R. 2001. Plant response following soil disturbance in a longleaf pine ecosystem. J. Torrey Bot. Soc. 128: 208-218.

Slocum, M.G., Platt, W.J. \& Cooley, H.C. 2003. Effects of differences in prescribed fire regimes on patchiness and intensity of fires in subtropical savannas of Everglades National Park, Florida. Restor. Ecol. 11: 91-102.

Sokal, R.R. \& Rohlf, F.J. 1995. Biometry. 3rd. ed. W.H. Freeman and Co. New York, NY, US.

Sparks, J.C., Masters, R.E., Engle, D.M., Palmer, M.W. \& Bukenhofer, G.A. 1998. Effects of late growing-season and late dormant-season prescribed fires on herbaceous vegetation in restored pine-grassland communities. J. Veg. Sci. 9: 133-142.

Streng, D.R., Glitzenstein, J.S. \& Platt, W.J. 1993. Evaluating season of burn in longleaf pine forests: a critical literature review and some results from an ongoing long term study. Proceedings Tall Timbers Fire Ecology Conference 18: 227-263.

Tabachnick, B.G. \& Fidell, L.S. 1996. Using Multivariate Statistics. 3rd. ed. Harper Collins College Publishers. New York, NY, US.

Vandermeer, J.H., Boucher, D.H., Perfecto, I. \& Granzow-de la Cerda, I. 1996. A theory of disturbance and species diversity: evidence from Nicaragua after Hurricane Joan. 
Biotropica 28: 600-613.

Walker, J. \& Peet, R.K. 1983. Composition and species diversity of pine-wiregrass savannas of the Green Swamp, North Carolina. Vegetatio 55: 163-179.

Weakley, A.S. 1999. Flora of the Carolinas, Virginia, and Georgia. Working Draft of 1999. University of North Carolina Herbarium, North Carolina Botanical Garden, Chapel Hill, NC, US.
Whelan, R.J. 1995. The ecology of fire. Cambridge University Press, Cambridge, UK.

Williams, L.R., Cameron, G.N., Spencer, S.R., Eshelman, B.D. \& Gregory, M.J. 1986. Experimental analysis of the effects of pocket gopher mounds on Texas coastal prairie. J. Mammal. 67: 672-679.

Received 28 July 2004; Accepted 9 July 2005. Co-ordinating Editor: F.S. Gilliam. 